\title{
Does Corruption Hinder Private Businesses? \\ Leadership Stability and Predictable Corruption in China
}

(forthcoming in Governance: An International Journal of Policy, Administration, and Institutions)

\author{
Jiangnan Zhu \\ Assistant Professor \\ Department of Politics and Public Administration \\ University of Hong Kong \\ zhujan@hku.hk \\ Dong Zhang \\ Ph.D. Candidate \\ Department of Political Science \\ Northwestern University \\ dongzhang2015@u.northwestern.edu
}

\begin{abstract}
We study whether corruption hinders businesses by investigating China's private enterprises, which have developed rapidly despite high corruption levels. We argue that a key factor determining the effects of corruption is corruption predictability, which is significantly influenced by government leadership stability. When the same leaders remain in major offices for long tenures, corruption is relatively predictable, reducing hindrance to businesses. When leaders change frequently, entrepreneurs need to constantly cultivate new connections with officials and face more uncertainty; therefore, corruption becomes a major obstacle. We conduct field interviews to explore channels through which leadership stability encourages predictable corruption. We also use the 2012 World Bank Enterprise Survey of Chinese private firms and develop a novel measure of leadership stability of the local Chinese government based on a selfcollected data set of municipal party committees to test our hypotheses. Results of various models are consistent with our hypotheses.
\end{abstract}




\section{Introduction}

To what extent does corruption, a manifestation of low government quality, jeopardize business operation? Some scholars argue that corruption discourages private investment by distorting the allocation of entrepreneurial talents and resources (e.g., Mauro 1995; Méon and Sekkat 2005; Murphy, Shleifer, and Vishny 1991); others suggest that corruption helps entrepreneurs circumvent cumbersome regulations and overcome the high threshold of firm entry (e.g., Dreher and Gassebner 2013; Leff 1964; Méon and Weill 2010; Huntington 1968). To resolve this theoretical debate, we analyze the conditions under which corruption facilitates or hinders business operations by using the case of China's private enterprises, which have been the major economic engines in many localities in the reform era while often victimized by corruption ( $\mathrm{Li}$ and Xia 2008).

We argue that a key factor determining the effects of corruption on private businesses is corruption predictability, specifically certainty in outcomes and procedures of corrupt transactions (Wei 1997). Moreover, according to theories of the market structure of corruption (Shleifer and Vishny 1993), we contend that corruption predictability greatly depends on government leadership stability. Stable leadership, defined as the same small group of officials remaining in power for long tenures, can establish a predictable corruption regime that reduces corruption's hindrance to private business operations in weakly institutionalized countries. In the case of China, local political power is centralized to a small leader circle, and leadership stability varies considerably

across localities. Hence, China constitutes an appropriate case to examine the effect of leadership stability on corruption's hindrance to business operations. 
We use a mixed-method approach. First, we conduct field interviews to explore channels through which leadership stability encourages corruption predictability, particularly reinforcing the informal contract between bribers and bribees, easing firms' learning curve of corruption, and deterring harassment by low-level bureaucrats. Second, we draw on the 2012 World Bank Enterprise Survey data of 2700 firms in 25 Chinese prefectures to test the effects of leadership stability on corruption hindrance. We develop a novel measure of leadership stability - the effective number of leaders-based on our self-compiled data set of 25 municipal party committees from 2002 to 2011 . We find that an increase in the effective number of leaders is associated with firms' heightened perception of corruption as an obstacle, suggesting that leadership stability reduces corruption's hindrance to business operations. Moreover, we document that effects of stable leadership are more pronounced for firms conducting business in a highly corrupt environment and highly regulated industries. Leadership stability also exerts larger impacts on small and medium firms than on large firms. These nuanced findings indicate that firms vulnerable to political uncertainty likely rely more on leadership stability to secure predicable corruption and facilitate business transactions. Thus, empirical findings are consistent with our overall theoretical predictions.

Therefore, our study shows that government may at least maintain relatively stable leadership to promote predictable corruption, which reduces hindrance to businesses in societies with serious corruption. Stable political connections can result in not only monetary benefits for firms (Faccio 2006; Fisman 2001) but also a stronger capacity to weather an unfriendly investment environment and envision the foreseeable future. We also extend previous studies of predictable corruption (e.g., Campos, Lien, and Pradhan 1999; Malesky and Samphantharak 2008) by identifying the institutional conditions and the affiliated causal pathways promoting corruption 
predictability. These theoretical implications altogether help demonstrate why China's private enterprises have flourished in numerous localities despite rampant corruption (Bo 2014; Wedeman 2012).

\section{Organization of Corruption and Leadership Stability: A Theoretical Framework}

Corruption, commonly defined as using public power for private gain, is sometimes considered parallel to taxes or fees (Svensson 2005). However, arbitrariness rather than extra payments makes corruption more predatory than tax (Wei 1997). Without transparency and enforcement between bribers and bribees, corruption creates more uncertainty for investors (Fisman and Svensson 2007). Firms paying more bribes may ultimately spend more, rather than less, management time in negotiating regulations with bureaucrats and bear higher, rather than lower, costs of capital (Kaufman and Wei 1999). In worst case scenarios such as that in Cambodia, when governors change because of elections, pre-existing corruption practices break down, followed by a significant decline in firm investments (Malesky and Samphantharak 2008). By contrast, predictable corruption may reduce corruption's hindrance to business operation. The high private capital flow found in several East Asian countries, including China, despite their high corruption levels is actually conjectured to result from higher corruption predictability in those countries (Campos et al. 1999). However, what institutional conditions reduce uncertainty and promote corruption predictability, and the channels through which these conditions work are unclear.

Andrei Shleifer and Robert W. Vishny (1993) argue that the structure of government institutions, strength of government in controlling its bureaucracies, and number of veto powers in the political process of a country are critical determinants of corruption level. A strong state with a centralized bureaucracy can set bribe prices for government provisions (e.g., business licenses) 
collectively by monopolistic bureaucracies and punish any deviations from agreed-upon corruption patterns. Conversely, corruption levels tend to increase in countries with a weak central government and decentralized administrative systems, because different ministries, public agencies, and local governments at various administrative levels all have incentives to set their own bribes independently to maximize their own income from bribes (Malesky and Samphantharak 2008). For example, private firms' returns on investment tend to decrease with more regulatory checks (Kaufmann 1996; Olken and Barron 2009).

In addition to corruption levels, the industrial organization's perspective of corruption gives insights into corruption predictability. For example, in regimes with a small ruling elite, such as monarchies and the former communist regimes, investors may be less concerned with corruption uncertainty. "It is always clear who needs to be bribed and by how much" (Shleifer and Vishny 1993, 605). Once a bribe is paid to relevant government bureaucrats, no additional bribes would be demanded. Moreover, the favor, service, or product being sought is guaranteed to be granted (Campos et al. 1999). For firms in such countries, the bribe schedule is "more or less transparent" with "more or less assurance of results... Bribe payment is like a tax, except that it goes into the bureaucrat's pocket rather than the government treasury" (Wei 1997, 2). However, in a political system with multiple veto powers, favors are not guaranteed, and the total payment is uncertain. For example, in India, where bribe taking is conducted in a decentralized way and corruption is less predictable, bribing an individual official in a line of many may not ensure faster file movement (Bardhan 1997, 1324).

Nevertheless, even in regimes in which officials monopolize power, government favors obtained through corruption may be terminated when the ruling cliques change and incumbent officials are reshuffled frequently (Campos et al 1999). For instance, in weakly institutionalized 
countries, even if elections are held regularly, the cabinet may change often, such as replacing the premier followed by replacing 50\% or more of cabinet ministers (Aisen and Veiga 2013). Although firms may pay additional bribes to the new officials, this only transforms corruption uncertainty into extra business costs. In other words, frequent leadership changes over time essentially increase the number of veto powers and thus add uncertainty to the bribe schedule and results. Therefore, we posit the corollary hypothesis that in weakly institutionalized societies, corruption predictability is higher when the same small group of officials remains in power for a long period (i.e., stable leadership) than when government officials are frequently replaced.

\section{Power Structure and Leadership Stability in China's Local State}

In China, political and economic systems were highly centralized in the pre-reform era. Although local leaders had considerable authority in their appointed jurisdictions, they had limited control over resources, which were allocated by the central government (Landry 2008). In the reform era, though the national government retains considerable control over the appointment and promotion of central- and provincial-level officials, much autonomy has been granted to local governments through economic decentralization (Landry 2008; Mertha 2005). Subnational governments, from provincial to county level, have overarching responsibility for "initiating and coordinating reforms, providing public services, and making and enforcing laws" (Xu 2011, 1078) and a primary control of a substantial amount of resources such as land, firms' financial resources, energy, and raw materials (Montinola, Qian, and Weingast, 1995; Xu 2011). Thus, officials at various administrative levels have many opportunities and incentives to seek rent and solicit bribes as the scope of market reform widened (Gong 1997; Wedeman 2012). Minxin Pei (2006, 13) even argues that corruption in China has changed from "centralized predation" (i.e., state predation by the ruler) to "decentralized predation" (i.e., predation by agents of the state). 
Nevertheless, power within each local government is centralized around the local party committee, comprising a small elite group that generally consists of the local party secretary; the governor; the deputy secretary and deputy governor, who oversee economies; the political-legal committee secretary (law enforcement); the disciplinary committee secretary; the secretarygeneral of the local party committee; and the heads of the organizational (personnel issues), propaganda, and united-front departments (co-opting social elites). As the highest decision-making body at each administrative level, the local party committee collectively determines the major agenda of a city, from economic policies, such as land acquisition and transaction for real estate and urban development, taxation, preferential treatment for firms, and the appointment and promotion of lower-level officials, to environmental protection and informational publicity and censorship. Under the local party committee, the chief and deputy chiefs of different party and government branches, legislative and political consultative bodies, state-owned enterprises, and other public institutions also wield substantial power within each functional unit. Altogether, these key party and state cadres constitute local leadership in China (Sun 2008). Therefore, the local government structure in China is conducive to predictable corruption because a relatively small number of political leaders is maintained within each subnational governmental jurisdiction. In small cities and county levels and lower, business bidders can fulfill their needs by only sending tributes to the chief executive office (Sun 2006; Zhu and Wu 2014). In this circumstance, if the major leaders stay in power for long tenures, they can further promote corruption predictability and reduce corruption's hindrance to business operations.

However, leaders' tenures vary case by case. The Chinese Communist Party in the postMao era has restored and developed its cadre management system to ensure massive qualitative elites for the modernization drive and to rationalize the previously often turbulent leadership 
turnovers (Manion 1985). One reform was adding term limits and age requirements for retirement (Li 2012). "According to Article 106 of the state constitution and Article 26 of the party constitution, respectively, the term of office of the local territorial chief executives and party secretaries should all be five years" (Guo 2009, 624). In practice, the observed term in office is often shorter than five years because local leaders may leave their post prematurely for various reasons, ${ }^{1}$ including promotion to higher positions, rotation to other rank-equivalent positions, retirement owing to old age or poor health, and demotion or removal after a corruption scandal (Guo 2009). Transfer, retirement, and prosecution are normally beyond the control of local leaders and exogenous to local firms. Thus, local leadership composition changes occasionally. Whereas the same group of leaders stays in power for a relatively long time in some local governments, other governments may experience more leadership turnover in a short period. Figure 1 illustrates the power structure of local leadership in China. Therefore, leadership stability varies across localities in China, leading to different levels of corruption predictability and ultimately varying degrees of hindrance to private enterprises according to our theoretical prediction.

\section{Figure 1 Inserted Here}

\section{Why Leadership Stability Is Crucial to China's Private Enterprises}

We further explore channels through which leadership stability affects corruption predictability for China's private enterprises. Undeniably, China has heavily promoted private enterprises, particularly since the mid-1990s (Dickson 2008). The Chinese government has increased the use of contracts and implemented new formal rules, legal rights, and modern corporate forms, which have enabled private firms to clarify their ownership structures and the relationship with their sociopolitical environment. Nevertheless, the enduring Leninist control has generated "institutional ambiguities" in the governance of China's private sector (McNally 2011, 
3). For example, protecting property rights, which is necessary to ensure entrepreneurial incentives, has been inefficient. Except a few local governments (e.g., Wenzhou and Taizhou) which were protective and supportive of private enterprises in the 1990s, most subnational governments were initially cautious or even hostile to private firms (Xu 2011). Large state-owned enterprises and foreign companies have been systematically favored at the expense of indigenous private firms, particularly small firms, because they "contradict the goal of major Chinese cities to become world-class cities" (Wang 2014, 221). Private firms also experience factor resource underallocation and are considerably blocked from entering strategic sectors such as energy and steel because of the state's monopoly on profits ( $\mathrm{Li}$ and Xia 2008). Meanwhile, the local state essentially controls local rules and many key resources; in absence of public supervision, the local state is more frequently observed as a grabbing hand than a helping hand for private sectors (Huang 2008). Thus, private entrepreneurs must cultivate networks in party-state institutions to build trust with officials, overcome government indifference, access scarce resources, and compensate for institutional uncertainty (McNally 2012; Wank 1999). Businessmen pay bribes to "either obtain some good or avoid suffering some bad at the hands of corrupt officials" (Wedeman 2012, 6). Most corruption since the 1990s involves mutually beneficial exchanges between government officials and private businessmen (Manion 2013). According to our field interviews and publicly accessible news reports, we argue that stable leadership makes corruption predictable and reduces the hindrance to business in three main ways: 1) facilitating a virtual contract that increases firms' assuredness of favorable results, 2) providing a transparent bribe schedule that eases firms' learning curve of corruption, and 3) protecting firms from harassment by low-level bureaucrats. 
First, leadership stability can increase firms' assuredness of favorable results. Regular government alternation often causes policy uncertainty and changes in government capacity (Feng 2001). Favors such as preferential treatment granted to private firms on the basis of personal relationships between entrepreneurs and government officials are even more likely to be arbitrary and fluctuate with leadership changes. For example, the president of Wantong Pharmacy, a large private enterprise, commented that firms are most afraid of government leaders coming and going frequently like taking tours (zouma guanhua de huanren), because many agreements signed previously may not count anymore and need to start over after leadership turnovers, therefore wasting a large amount of resources of a company (Lang 2015). Similarly, in our interview, a Singaporean entrepreneur who ran a joint venture with Chinese private firms complained that "sometimes, when a new leader came, we were even asked to pay back the waived taxes in the previous years by the former leader. We had to look for consulting firms to help smooth out relations with the leaders."2 Other interviewees also mentioned similar problems. By contrast, stable local leadership can facilitate a virtual contract between business owners and the government, freeing private businesses from capricious reactions from new government "partners." Li (2011) observes that the contracting process of bribery between businesses and the government is facilitated in a constructed social setting of commitment and reciprocity, which is gradually built up in private firms' long-term cultivation with stable leadership.

The virtual contract between officials and entrepreneurs is more crucial for corrupt exchanges "having a time lag and geographic separation between the bribe payment to the corrupt official and delivery of the public good to the briber" ( $\mathrm{Li}$ and $\mathrm{Wu} 2007,5-6)$. Without enforcement of contracts, bribers and corrupt officials would hesitate to deliver their offer first, potentially 
leading to failed transactions. With stable leadership, more mutual trust exists between officials and entrepreneurs, promoting cooperation between corrupt officials and bribers.

Second, stable leadership can provide firms with a transparent bribe schedule and costefficient means to achieve the designated goal. In corruption exchanges, firms must develop tactical skills to deal with different government agencies, such as learning who to bribe, how much to pay, when to pay, and what to pay. For example, government-uncovered corruption cases show that corrupt officials exhibit diverse preferences, including money, mistresses, and luxury products. Establishing corrupt relationships with unfamiliar officials can also be risky "because the first one who is explicit about wanting to make or accept a payoff at the mercy of the others who can threaten to report the illegal act" (Rose-Ackerman 1999, 101). Thus, bribing constitutes a learning curve that costs time, money, and sometimes even legal punishment when not conducted carefully. The cost tends to be particularly high during initial trials (Ohlsson 1992). With the same group of leaders in power, the amount of bribes and the norms of corruption are stable and well known by the bribers and bribees (Malesky and Samphantharak 2008). With more experience, firms' cost to execute corruption substantially decreases.

Chinese private enterprises reportedly spend 5\%-30\% more time than do nonprivate enterprises in cultivating relationships with government officials to obtain what they are entitled to and to secure preferential treatment (Lang 2015). In addition, private firms spend a huge amount of money on officials. A private entrepreneur who nearly went bankrupt complained that to entertain local officials in 2008 , he spent 300,000 yuan, which was $20 \%$ of firm profits of that year. This entrepreneur also said that the private firms that could survive and thrive are those investing tremendous amount of public relationship building fees on officials annually, such as Baidu, or those with government connections, such as Huawei. ${ }^{3}$ Thus, the same officials staying in power 
may save entrepreneurs time and money that would otherwise be utilized to build and maintain new connections. In a field interview in a county-level city in Shandong province, a private entrepreneur who owned a construction company said that "We (private entrepreneurs) especially like the situation when the same leader stays in the key office, such as a local party secretary, for a long tenure. If he can concurrently hold multiple positions, it would be even better. This is because making friends with this one person and maintaining friendship only with him can help me get many things done. ${ }^{4}$ A manager of a large fishery company in Hainan province told us that though the company deals with several local government offices, it mainly maintains relationships with officials by "visiting them" during major holidays. Because of considerable familiarity with those officials, corruption is not perceived as a major obstacle of the company's business operation. However, with leadership turnover and new leaders in power, the company usually has to spend at least three to six months to establish relationships with officials. ${ }^{5}$

Finally, stable leadership can transmit predictable corruption from officials at higher levels to those at the grassroots levels, making the entire corruption regime predictable. Many firms actually more frequently interact with low-level bureaucrats than local high-level officials. Stable government leadership, compared with frequently changing leadership, is more likely to retain the existing government rank and file, which eases firms' interaction with low-level bureaucrats. In particular, stable connections with local leaders protect firms from harassment by street-level bureaucrats. For example, several interviewees described similar stories about how they dealt with extortion by taxmen or various safety inspectors, which is a common problem faced by Chinese private enterprises. Entrepreneurs normally use expensive drinks and food or small gifts to resolve such problems. However, when "inspections" are conducted more frequently, well-connected private entrepreneurs would reveal their friendship with local leaders to deter disturbances. ${ }^{6}$ 
Generally, corrupt relationships may be easier to maintain within the same small group, because honesty, reliability, and trust have been established (Rose-Ackerman 1999). When a bribe schedule is predictable and available, firms may "simply build informal charges into their business plans, just as they would with any other additional costs" (Malesky and Samphantharak 2008, 288). In this case, corruption's hindrance to business operation is considerably reduced. The following text summarizes our testable hypothesis, and causal pathways are illustrated in Figure 2:

Hypothesis: More stable leadership, defined as the same small group of officials remaining in key offices for long tenures, makes corruption more predictable for private entrepreneurs than frequent leadership turnover. With stable leadership, corruption's hindrance is consequently reduced for business operation.

\section{Figure 2 Inserted Here}

\section{Leadership Stability and Corruption's Hindrance to Businesses:}

\section{Empirical Strategy and Results}

We test our hypothesis by using the World Bank Enterprise Survey in China conducted between December 2011 and February 2013. A total of 2700 privately owned enterprises were successfully interviewed through stratified random sampling. Compared with simple random sampling, stratified random sampling is a more favorable method for obtaining unbiased estimates for different subdivisions of the population with a known level of precision and unbiased estimates for the whole population of privately owned firms (Lohr 1999). The survey used three stratification levels: industry, establishment size, and region. The universe of industries was stratified into 11 manufacturing industries and seven service industries, as defined in the sampling manual. ${ }^{7}$ Size stratification was defined following the standardized definition for rollout: small (5-19 employees), 
medium (20-99 employees), and large (>99 employees). The survey was conducted in 25 metros (Figure 3).

\section{Figure 3 Inserted Here}

We measure our dependent variable of hindrance of corruption according to firms' answers to the question "To what degree is corruption an obstacle to the current operations of this establishment?" Answers included "No obstacle (0)," "Minor obstacle (1)," "Moderate obstacle (2)," "Major obstacle (3)," "Very severe obstacle (4)," and "Don't know or does not apply." Among surveyed firms, $73.7 \%$ said they considered corruption as no obstacle, $19.9 \%$ as a minor obstacle, $3.56 \%$ as a moderate obstacle, and $0.96 \%$ as a major or very severe obstacle. Only $1.18 \%$ of firms replied "Don't know or does not apply." In the complete sample, most firms responded that corruption was not an obstacle to business operation; however, notably, the answer varied considerably depending on the city. In cities such as Dalian, Hefei, and Nanjing, nearly $90 \%$ of firms said they considered corruption as no obstacle; the ratio was approximately 55-59\% in Ningbo and Wuhan and only $36.5 \%$ in Foshan. To facilitate analysis, we collapse firms' responses to the question into a dichotomous variable, obstacleindex. Answers of no obstacle are coded as 0 and minor to severe obstacles as 1 , indicating higher hindrance to private firms. ${ }^{8}$

To measure the independent variable of leadership stability, we compile a data set of the members of each municipal party committee of the 25 cities from 2002 to 2011 by the survey year. As mentioned, the local party committee usually consists of the nine most powerful political leaders of a city. Every committee member wields substantial power in the city, takes care of several different policy arenas, and has wide connections in different sectors within the jurisdiction. Therefore, the committee's stability can, to a large extent, determine the general stability of the 
local cadre corps, the stability of formal policies, and, importantly, the stability of the informal network between firms and government officials.

To the best of our knowledge, our study is the first to utilize data of all municipal committee members; previous studies have usually focused on one or two topmost leaders. We compile the data set by complementarily searching government websites, municipal party newspapers, and speeches recorded in statistical yearbooks of cities and Baidubaike (baike.baidu.com). Most cities experienced at least one or two leadership turnovers over the 10-year study period. During leadership turnovers, new leaders were sometimes assigned to the city or transferred between positions; for example, they were promoted from mayor to party secretary or moved from the political-legal committee to the disciplinary committee. In some cases, the same leader stayed in the same position for many years.

We develop the variable "the effective number of leaders of a party committee" to capture varying degrees of leadership stability. It is reasonable to assume that over a 10-year period, committee members with longer tenures tend to wield more de facto power because of their knowledge about and informal powerbase within the locality. This is also related to the prevalent informal politics of China, wherein party elders' opinions are usually more crucial than those of newcomers (Huang 2000). Hence, though a party committee often consists of nine members annually, the essentially effective or influential number of committee members may be fewer than nine. Therefore, we adopt the approach used for calculating the effective number of electoral parties within the legislature (Equation 1, Laakso and Taagepera 1979) as follows:

$$
N=\frac{1}{\sum_{i=1}^{n} p_{i}^{2}}
$$

Equation (1)

In the original equation, $\mathrm{p}$ is the proportion of seats held by a party within a legislature, and $\mathrm{n}$ is the number of parties with at least one seat. In our study, we consider each committee member 
as a party and their number of years served in the committee within the 10 years as their number of seats in the legislature. We calculate the number of effective leaders of a local party committee over a 10-year period. Higher numbers imply more political turnover and less leadership stability, and lower numbers imply that the same group of leaders stayed in the positions for long tenures. Figure 4 shows the generally positive correlation between the number of effective leaders and the average obstacleindex of cities.

\section{Figure 4 Inserted Here}

We also use two alternative measures for leadership stability. First, the number of different officials (number of leaders) appearing in the 10-year name list of a party committee: more names imply more leadership turnover and less leadership stability. Second, the sum of the top two longest tenures among all party committee members in a city (max_top2_leader): higher numbers imply that the same group of leaders had longer tenures and more leadership stability.

To consider confounding variables, we control for a rich set of variables at the firm and city levels. At the firm level, we control for the firm's industrial sector, firm size, share of private capital in the firm, and court justice perception. Court justice measures the quality of formal institutions by averaging firms' response to the question, "Is the local court system fair, impartial and uncorrupted?" Answers to this question are scored from 1 (strongly disagree) to 4 (strongly agree). Thus, a higher score implies more court justice and a more favorable formal institutional environment of a city. At the city level, we control for the urbanization level (urban population/total population), fiscal income as share of gross domestic product (GDP) in 2011, population size in 2011 (logged), GDP per capita in 2011, and economic structure measured by the share of industrial output in total GDP. We also control for the corruption level proxied by administrative expenditure per capita of a city in $2005,{ }^{9}$ assuming that more administrative 
expenditure indicates a higher government budget for public servants and a higher potential of official corruption (Kung and Chen 2015; Gong and Xiao 2015). Descriptive statistics are summarized in Table 1. Because our dependent variable is dichotomous, we use the logit model to test our hypothesis. Our models to be estimated are as follows:

$$
\operatorname{logit}(\text { obstacleindex })=\alpha_{1} \text { Eff_num_leader }+\beta_{1} X_{i}+\beta_{2} \mathrm{~W}_{\mathrm{j}}+\xi_{\mathrm{i}}
$$

Equation (2),

where $\mathrm{i}$ indexes a city and $\mathrm{j}$ indexes a firm. $\mathrm{X}_{\mathrm{i}}$ is a vector of city-level economic control variables, including fiscal income as share of GDP, GDP per capita, industry output as share of GDP, urbanization rate, and logged city population and logged municipal administrative expenditure per capita. $\mathrm{W}_{\mathrm{j}}$ is a vector of firm-level characteristics, including industry sector, firm size, private capital share, and court justice perception.

\section{Table 1 Inserted Here}

\section{Main Results}

Table 2 presents the effects of leadership stability measured by the effective number of leaders on obstacleindex. In column 1, a parsimonious model without any control variables shows that higher effective numbers of leaders in the party committee increase corruption's hindrance to firms. Moreover, the average marginal effect suggests that, if leader numbers increase by one between 2002 and 2011, the probability of firms perceiving corruption as an obstacle increases by $2 \%$ on average. In our sample of 25 cities, the number of effective leaders ranges from 12.67 to 20.47. Thus, firms in cities with the highest number of effective leaders were $16 \%$ more likely to perceive corruption as an obstacle to business operation than firms in cities with the lowest number of effective committee members over 10 years. Because $24.4 \%$ of all firms, on average, perceived 
corruption as obstacle, a difference of $16 \%$ and a marginal effect of $2 \%$ of the number of leaders can be considered substantial.

Column 2 controls for firm size and firm industry dummies to account for divergent firm characteristics. Results remain significant at the 5\% level. Column 3 incorporates two firm-level control variables in the model: the share of private capital of the firm and a firm's perception of court justice. Column 4 controls for a battery of city-level variables to account for variation in economic development, economic structure, demographic features, and fiscal resources across cities. The magnitude and significance of the estimated coefficient of effective number of leaders is fairly robust. In addition to the independent variable, private firms' perception of corruption as an obstacle increases with industrialization of the local economy. Consistent with our conjecture, more government administrative expenditure, i.e., higher corruption potential, constitutes a major obstacle to business operation.

Although we have controlled for a set of potential confounding variables, we are aware that our analysis is hardly immune from omitted variable bias. To alleviate this concern, we examine the extent to which omitted variables may affect our findings according to the insight that the bias from observed controls is informative about the bias from unobserved controls (Altonji, Elder, and Taber 2005). If we consider column 1 as a restricted model and column 4 as the full model, the lower bound of the true coefficient is $0.101 .^{10}$ Moreover, the relationship between omitted variables and our dependent variable must be over 13 times stronger to explain away the entire effect we have identified (Bellows and Miguel 2009) ${ }^{11}$. Therefore, our results are unlikely to be vulnerable to omitted variable bias. ${ }^{12}$

In Table 3, we use two alternative measures of leadership stability as independent variables. Columns 1 and 2 report the effects of the number of leaders on obstacleindex. The average 
marginal effect test in column 2, which incorporates all control variables, shows that if the number of leaders increases by one, the probability of perceiving corruption as a business obstacle increases by approximately $1.7-2.1 \%$ on average. Columns 3 and 4 report the effects of the sum of the top two longest tenures among all party committee members. The results indicate that if the top two longest-tenured leaders stay for one more year in the committee, the probability of firms perceiving corruption as an obstacle decreases by $2.7 \%$ on average. To summarize, alternative measures of leadership stability yield results similar and consistent to those of our main indicator.

We also use hierarchical models to check the robustness of our findings, because we include variables at the macro city and micro firm levels. The results in Appendix A are consistent with the findings in Tables 2 and 3. We find that the magnitude of the estimated effect becomes slightly higher in the hierarchical models. We also run logit regressions within the subsample of firms established before 2003, because firms established after 2003 may not have been influenced by the local party committee since 2002 . Actually, $66 \%$ of the sampled firms were established before 2003. The results in Appendix B are consistent with those of the baseline regressions, and the effects of independent variables become more significant. Thus, altogether, our hypothesis is buttressed by empirical tests.

\section{Table 2 Inserted Here}

\section{Table 3 Inserted Here}

\section{Conditionally Stronger Effect of Leadership Stability}

We further test our hypothesis, particularly the intermediating effect of predictable corruption, by exploring the heterogeneous effects of leadership stability on perceived hindrance of corruption. If our hypothesis holds true, one implication is that predictable corruption is crucial for firms plagued by high corruption levels and that they should depend more on political ties to 
facilitate their business operations. Leadership stability is crucial in these cases. We use a linear model with an interaction term and follow the approach of Brambor et al. (2006) to display the marginal effects of leadership stability corresponding to changes in corruption level. Figure 5 clearly illustrates that with increased corruption levels, the effect of leadership stability on obstacleindex increases. For example, the effect of leadership stability increases more than twofold from $2 \%$ to approximately $5 \%$ as corruption level increases from five to six, where most observations are distributed.

\section{Figure 5 Inserted Here}

The effect of leadership stability may also change with firms' size and industry which dictates their demand for predictable corruption. Table 4 presents results for different subsamples. Columns 1-3 report the effect in small, medium, and large firms, respectively. The effect of the effective number of leaders is significant in small and medium firms but insignificant in large firms. A plausible explanation is that smaller firms likely rely more on local political connections and, thus, are more susceptible to local leadership turnover that affects the predictability of local corruption regime. By contrast, large firms are politically influential (Lorentzen, Landry, and Yasuda 2014). Some of them are even connected to higher political authorities that shield them from being predated by corruption uncertainty caused by local leadership changes (Wang forthcoming). In addition, market entry barriers vary by industry. In industries heavily regulated by the government, firms often rely more on their political connections to obtain entry permissions. Thus, leadership stability and its affiliated predictable corruption should be more crucial to those industries. According to the indicators of entry barriers reported by Chen et al. (2008), we group firms into two subsamples: those in highly regulated industries and those in less regulated industries. ${ }^{13}$ As illustrated by columns 4 and 5, the effect of leadership stability is higher in highly 
regulated industries than in less regulated ones. The marginal effect on average was approximately $2.5 \%$ for firms in highly regulated industries. Firms operating in cities with the highest number of effective leaders were $20 \%$ more likely to perceive that corruption hinders business operation than firms in cities with the lowest number of effective leaders. These results indirectly suggest that predictable corruption exerts an intermediating effect on leadership stability's impact on corruption's hindrance to private businesses.

\section{Table 4 Inserted Here}

\section{Conclusion}

This study has examined the case of China's private enterprises. We show that when corruption is prevalent, stable local leadership can increase the predictability of the corruption regime, thereby reducing corruption's hindrance to business operation. In particular, our field interviews reveal that stable leadership can promote predictable corruption by assuring favorable results to firms, making the transaction procedure more cost-efficient in terms of information, time, and money. Combining the 2012 World Bank Enterprise Survey and a self-compiled data set of local party committees of 25 cities surveyed by the World Bank, we also empirically document that private firms in cities with stable leadership perceive less hindrance of corruption than do those in cities with frequent leadership turnover. Moreover, the positive effects of leadership stability were prominent in situations wherein firms rely more on political connections to facilitate business operation, such as being plagued by higher corruption levels and in smaller sizes or highly regulated industries. These results indirectly support the conjectured intermediating role of predictable corruption linking leadership stability and corruption's hindrance to businesses.

Our study makes several notable contributions. First, it enriches the literature of government structure of veto powers and corruption (Shleifer and Vishny 1993; Bardhan 1997) by 
showing that power concentration may affect corruption levels, and that leadership continuity may influence the predictability of the corruption regime. This explains why corruption's hindrance to private businesses varies considerably across Chinese cities with similar government structure. Second, our findings also provide insights on the coexistence of astonishing economic growth and a high level of predatory corruption in China since 1978 (Bo 2014; Wedeman 2012). Existing studies emphasize the incentivization of local economic growth by formal institutions such as through decentralization or the Chinese nomenclature system (Landry 2008; Li and Zhou 2005; Xu 2011). We bridged formal and informal institutions by showing that the formal power structure of Chinese subnational governments can potentially stabilize informal business-government relationships. This finding also clarified the mechanism by which corruption functions as propertyprotection institutions in some countries (Faccio 2006; Johnson et al. 2000; Wang 2014). Essentially stable informal interpersonal connections enable relatively credible commitment to investors at officials' personal level (North 1990; Olson 1991), which facilitates commerce, though this not as ensured as that by formal institutions. Third, our study also warns policy makers of the potential costs of frequent rotation of local government officials in China in recent years. For example, at the county level, $96 \%$ of party secretaries and $97 \%$ of chief executives were involved in interlocality cadre exchanges from 1995 to 2001 (Guo 2008). Although this may increase officials' governing experience, it creates more uncertainty of local policies for private entrepreneurs and forces them to frequently cultivate new connections with newcomers, thus discouraging private investments.

Overall, our study shows that when informal institutions are relatively stable and corruption is predictable, corruption may facilitate business operation or at least reduce hindrance to commerce. Admittedly, our theoretical framework applies more to countries with centralized 
corruption than to consolidated liberal democracies, where corruption is generally under control and its threat to businesses is less influenced by regular leadership change, or to weak states, where corruption is largely decentralized. Future research could also identify direct measures of corruption predictability through surveys or experiments and conduct cross-country comparisons to further test the validity of our theoretical framework. Moreover, the situation under discussion in this study is still the second best outcome with high costs. A high-quality government with little corruption is always the ideal environment for business operation.

\section{Notes}

1. See Lu and Landry (2014) and Shih, Adolph, and Liu (2012) for official mobility in China.

2. Field interview conducted in Singapore in July 2015.

3. http://toutiao.com/a3664737831/

4. Field interview conducted in Zibo Shandong in January 2015.

5. Interview conducted in Hainan in July 2015.

6. Interview conducted in Shanghai in June 2015.

7. For details of the survey and sampling manual, see http://www.enterprisesurveys.org/documents/Implementation_note.pdf

8. Ordered logit regression results based on noncollapsed answers are consistent with our major findings and available on request to authors.

9. 2005 is the most updated year of data available.

10. The lower bound of the true coefficient can be calculated as $0.104-(0.107-0.104)=$ 0.101

11. The estimated coefficient of the restricted model divided by the difference in the estimated coefficient between the restricted model and the complete model. We consider column 3 with the largest estimated coefficient as the restricted model and column 4 as the complete model to obtain the minimum effect of omitted variables to explain our entire effect.

12. We examine the individual effects of municipal party secretaries and mayors because they are the top two officials of a city and their stability may individually exert a strong influence on corruption predictability. However, regression results do not support this conjecture. The results are available upon request.

13. Highly regulated industries include refined petroleum product, nonmetallic mineral products, basic metals, fabricated metal products, transport machines, construction, and transport 


\section{References:}

Aisen, Ari, and Francisco José Veiga. 2013. "How does Political Instability Affect Economic Growth?” European Journal of Political Economy 29: 151-167.

Altonji, Joseph G., Todd E. Elder, and Christopher R. Taber. 2005. "Selection on Observed and Unobserved Variables: Assessing the Effectiveness of Catholic Schools." Journal of Political Economy 113: 151-84.

Bardhan, Pranab. 1997. "Corruption and Development: A Review of Issues." Journal of Economic Literature 35(3): 1320-1346.

Bellows, John, and Edward Miguel. 2009. "War and Local Collective Action in Sierra Leone." Journal of Public Economics 93: 1144-1157.

Bo, Rothstein. 2014. "The Chinese Paradox of High Growth and Low Quality of Government: The Cadre Organization Meets Max Weber." Governance: An International Journal of Policy, Administration, and Institutions. Online first.

Brambor, Thomas, William Roberts Clark, and Matt Golder. 2006. "Understanding Interaction Models: Improving Empirical Analyses.” Political Analysis 14(1): 63-82.

Campos, J. Edgardo, Donald Lien, and Sanjay Pradhan. 1999. "The Impact of Corruption on Investment: Predictability Matters.” World Development 27 (6): 1059-1067.

Chen, Bin, Jian Yu, Xiaojin Wang and Jianqing Lai. 2008. "Empirical Study on the Development of Private Listed Companies." Shenzhen Stock Exchange Research Institute, Research Report.

Dreher, Axel and Gassebner Martin. 2013. "Greasing the wheels? The impact of regulations and corruption on firm entry." Public Choice 155(3): 413-432.

Dickson, Bruce. 2008. Wealth into Power: The Communist Party's Embrace of China's Private Sector. New York: Cambridge University Press.

Faccio, Mara. 2006. "Politically Connected Firms.” American Economic Review 96 (1): 369-386.

Feng, Yi. 2001. "Political Freedom, Political Instability, and Policy Uncertainty: A Study of Political Institutions and Private Investment in Developing Countries." International Studies Quarterly 45(2): 271-294.

Fisman, Rayman. 2001. "Estimating the Value of Political Connections." American Economic Review 91 (4): 1095-1102.

Fisman, Rayman, and Svensson Jakob. 2007. "Are Corruption and Taxation Really Harmful to Growth? Firm Level Evidence." Journal of Development Economics 83(1): 63-75.

Gong, Ting. 1997. "Forms and Characteristics of China's Corruption in the 1990s: Change with Continuity." Communist and Post-Communist Studies 30(3): 277-288.

Gong, Ting, and Xiao Hanyu. 2015. "The Formation and Impact of Isomorphic Pressures: The Case of Position-related Consumption in Chinese Bureaucratic Organizations”, working paper at City University of Hong Kong, Hong Kong. 
Guo, Gang. 2009. “China's Local Political Budget Cycles.” American Journal of Political Science 53 (3): 621-632.

Huang, J. (2000). Factionalism in Chinese Communist Politics. Cambridge: Cambridge University Press.

Huang, Yasheng. 2008. Capitalism with Chinese Characteristics: Entrepreneurship and the State. Cambridge: Cambridge University Press.

Huntington, Samuel P. 1968. Political order in changing societies. New Haven, CT: Yale University Press.

Johnson, Simon, Kaufmann Daniel, McMillan John, and Woodruff Christopher. 2000. "Why do firms hide? Bribes and unofficial activity after communism." Journal of Public Economics 76(3): 495-520.

Kaufmann, Daniel. 1996. "Diminishing Returns to Administrative Controls and the Emergence of the Unofficial Economy." Unpublished Manuscript. Washington, DC: The World Bank.

Kaufmann, Daniel, and Wei Shang-jin. 1999. "Does 'Grease Money' Speed Up the Wheel of Commerce?" Working paper 7093, National Bureau of Economic Research, Cambridge, MA.

Kung, James, and Chen Ting. 2015. "The Mystery of Authoritarian Growth: Land Revenue and the Career Concerns of China's Local Leaders." Working paper, Hong Kong University of Science and Technology.

Laakso, Markku, and Taagepera Rein. 1979. “"Effective' Number of Parties: A Measure with Application to West Europe". Comparative Political Studies 12(1): 3-27.

Landry, Pierre F. 2008. Decentralized Authoritarianism in China: the Communist Party's Control of Local Elites in the Post-Mao Era. New York, NY: Cambridge University Press.

Lang, Xianping. 2015. "To Encourage Innovation, Government Should Stop LawEnforcement in a Rent-seeking Manner." Available online at http://economy.caijing.com.cn/20150313/3839286.shtml

Leff, Nathaniel H. 1964. "Economic development through bureaucratic corruption." American Behavioral Scientist 8(3): 8-14.

Li, Cheng. 2012. "The End of the CCP's Resilient Authoritarianism? A Tripartite Assessment of Shifting Power in China." China Quarterly 211: 595-623.

Li, Hongbin, and Zhou Li-An. 2005. "Political turnover and economic performance: the incentive role of personnel control in China." Journal of Public Economics 89 (910): 1743-1762. 
Li, Ling. 2011. "Performing Bribery in China: guanxi-practice, corruption with a human face." Journal of Contemporary China 20(68): 1-20.

Li, Shaomin, and Judy Jun Wu. 2007. "Why China Thrives Despite Corruption?" Far Eastern Economic Review 170(3): 24-28.

Li, Shaomin, and Jun Xia. 2008. "The Roles and Performance of State Firms and NonState Firms in China's Economic Transition.” World Development 36(1): 39-54.

Lohr, Sharon L. 1999. Sampling: Design and Techniques. Boston: Cengage Learning.

Lorentzen, Peter, Pierre Landry, and John Yasuda. 2014. "Undermining Authoritarian Innovation: The Power of China's Industrial Giants." The Journal of Politics 76: 182-94.

Lu, Xiaobo, and Pierre Landry. 2014. "Show Me the Money: Interjurisdiction Political Competition and Fiscal Extraction in China." American Political Science Review 108 (3): 1-17.

Malesky, Edmund and Samphantharak Krislert. 2008. "Predictable Corruption and Firm Investment: Evidence from a Natural Experiment and Survey of Cambodian Entrepreneurs." Quarterly Journal of Political Science 3: 227-267.

Manion, Melanie. 1985. "The Cadre Management System, Post-Mao: The Appointment, Promotion, Transfer, and Removal of Party and State Leaders." China Quarterly 22: 203233.

Manion Melanie. 2013. The Challenge of Corruption. Presented at the Center for the Study of Contemporary China Annual Conference, Philadelphia, Pennsylvania, April, University of Pennsylvania.

Mauro, Paolo. 1995. "Corruption and Growth.” The Quarterly Journal of Economics 110(3): 681-712.

McNally, Christopher A. 2011. "China's Changing Guanxi Capitalism: Private Entrepreneurs between Leninist Control and Relentless Accumulation.” Business and Politics 13(2): article 5 .

McNally, Christopher A. 2012. "Sino-Capitalism: China's Reemergence and the International Political Economy." World Politics 64(4): 741-776.

Méon, Pierre-Guillaume, and Khalid Sekkat. 2005. "Does Corruption Grease or Sand the Wheels of Growth?" Public Choice 122(1): 69-97.

Méon, Pierre-Guillaume, and Laurent Weill. 2010. "Is Corruption an Efficient Grease?" World Development 38(3): 244-25.

Mertha, Andrew C. 2005. "China's 'Soft' Centralization: Shifting Tiao/Kuai Authority Relations." China Quarterly 184: 791-810. 
Montinola, Gabriella, Qian Yingyi, and Barry R. Weingast. 1995. "Federalism, Chinese Style: The Political Basis for Economic Success in China." World Politics 48 (1): 50-81.

Murphy, Kevin M., Andrei Shleifer, and Robert W. Vishny. 1991. "The Allocation of Talent: Implications for Growth.” The Quarterly Journal of Economics 106(2): 503-530.

North, Douglass C. 1990. Institutions, Institutional Change and Economic Performance. Cambridge University Press.

Ohlsson, Stellan. 1992. "The learning curve for writing books: Evidence from Professor Asimov." Psychological Science 3(6): 380-382.

Olken, Benjamin A. and Patrick Barron. 2009. "The Simple Economics of Extortion: Evidence from Trucking in Aceh.” Journal of Political Economy 117(3): 417-452.

Olson, Mancur. 1991. "Autocracy, Democracy, and Prosperity." In Strategy and choice, ed. RJ Zeckhauser. Cambridge: MIT Press.

Pei, Minxin. 2006. China's Trapped Transition: The Limits of Developmental Autocracy. Cambridge, MA: Harvard University Press.

Rose-Ackerman, Susan. 1999. Corruption and Government: Causes, Consequences, and Reform. Cambridge: Cambridge University Press.

Shih, Victor, Christopher Adolph, and Liu Mingxin. 2012. "Getting Ahead in the Communist Party: Explaining the Advancement of Central Committee Members in China." American Political Science Review 106(1): 166-187.

Shleifer, Andrei, and Robert W. Vishny. 1993. "Corruption." The Quarterly Journal of Economics 108(3): 599-617.

Sun, Yan. 2008. "Cadre recruitment and corruption: what goes wrong?" Crime, Law and Social Change 49(1): 61-79.

Svensson, Jakob. 2005. "Eight Questions about Corruption.” Journal of Economic Perspectives 19(3): 19-42.

Wang, Yuhua. Forthcoming. "Beyond Local Protectionism: China's State-Business Relations in the Last Two Decades." China Quarterly.

Wang, Yuhua. 2014. "Institutions and Bribery in an Authoritarian State." Studies in Comparative International Development 49(2): 217-241.

Wank, David L. 1999. Commodifying Communism: Business, Trust, and Politics in a Chinese City. Cambridge: Cambridge University Press.

Wedeman, Andrew. 2012. The Double Paradox of Rapid Growth and Rising Corruption in China. Ithaca, NY: Cornell University Press. 
Wei, Shang-Jin. 1997. "Why is Corruption So Much More Taxing than Tax?

Arbitrariness Kills.” Working Paper 6255. Cambridge, MA: National Bureau of Economic Research.

$\mathrm{Xu}$, Cheng-Gang. 2011. "The Fundamental Institutions of China's Reforms and Development." Journal of Economic Literature 49(4): 1076-1151.

Zhu, Jiangnan, and Yiping Wu. 2014. "Who Pays More "Tributes" to Government? Sectoral Corruption of China's Private Enterprises." Crime, Law, and Social Change 61: 309-333.

Acknowledgement: The authors thank all the participants of the Quality of Governance Conference held in October 2015 at Fundan University for their valuable comments. Special thanks go to Robert Cox, Yijia Jing, Alasdair Roberts, Shunfeng Song, Joseph Wong, Yiping $\mathrm{Wu}$, Xueyong Zhan, Guang Zhang, and our two anonymous reviewers for their inspiring suggestions and also Siqin Kang, Sarah Ho, Yingying Ho, Jia Zeng, Xiaoming Zhong, and Gesang Zhuoma for their excellent research assistance to this project.

Figure 1. Power structure of local China since economic reform

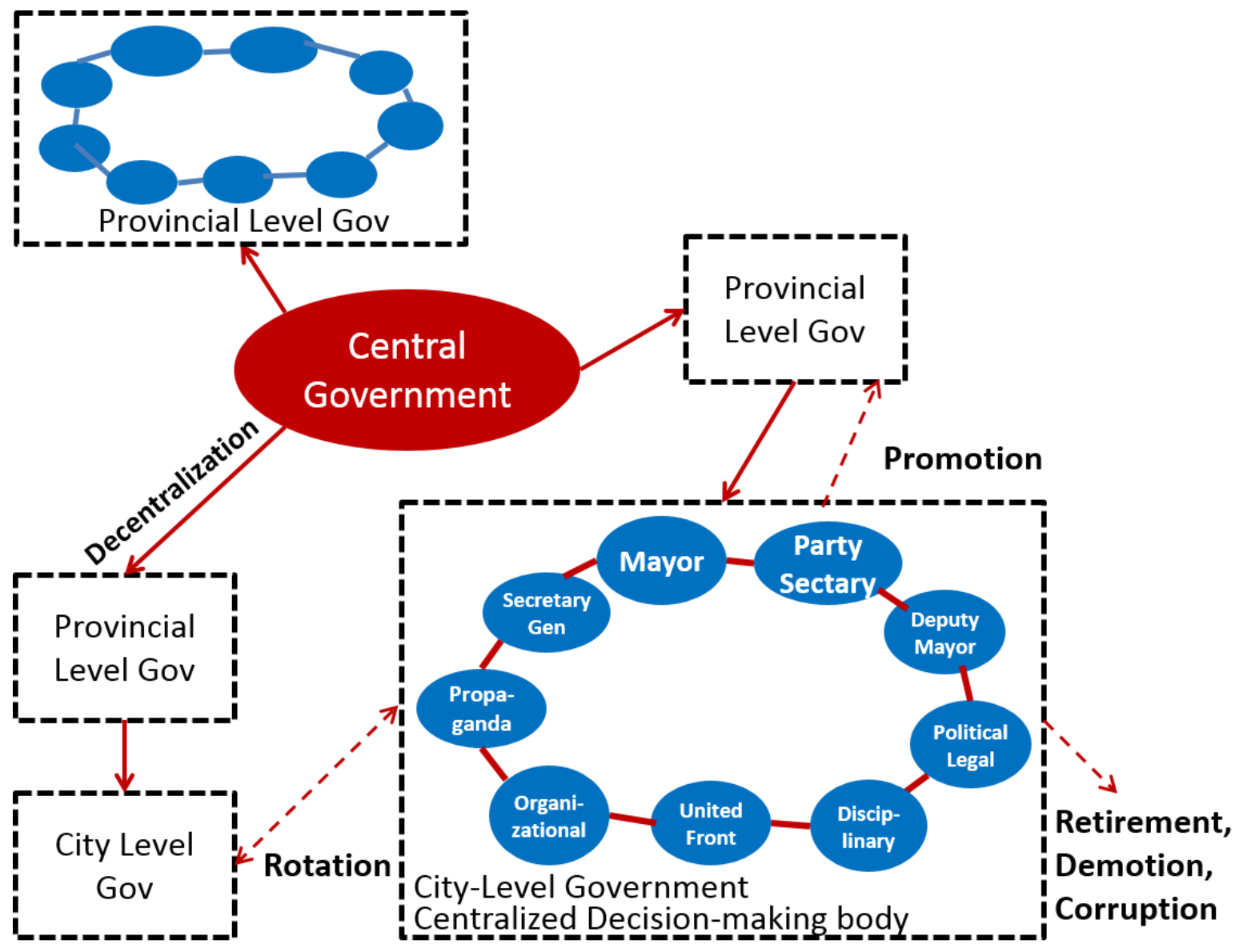


Figure 2. Leadership stability, predictability, and hindrance of corruption

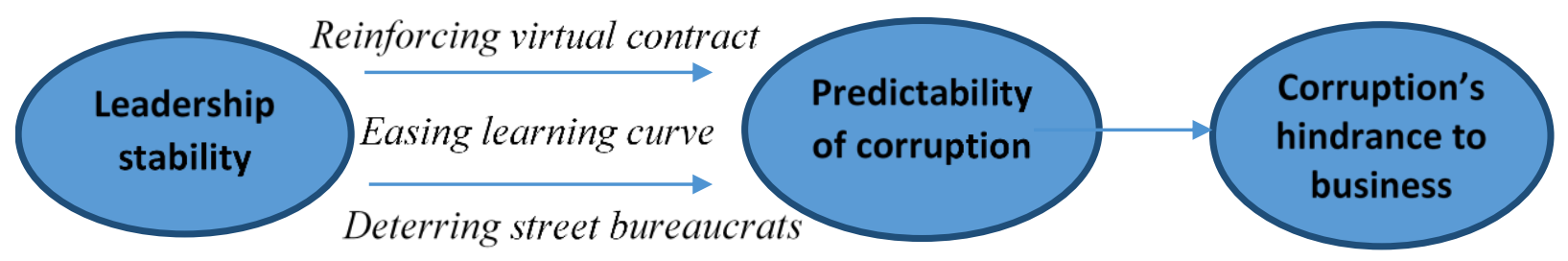

Figure 3. Metros surveyed in China

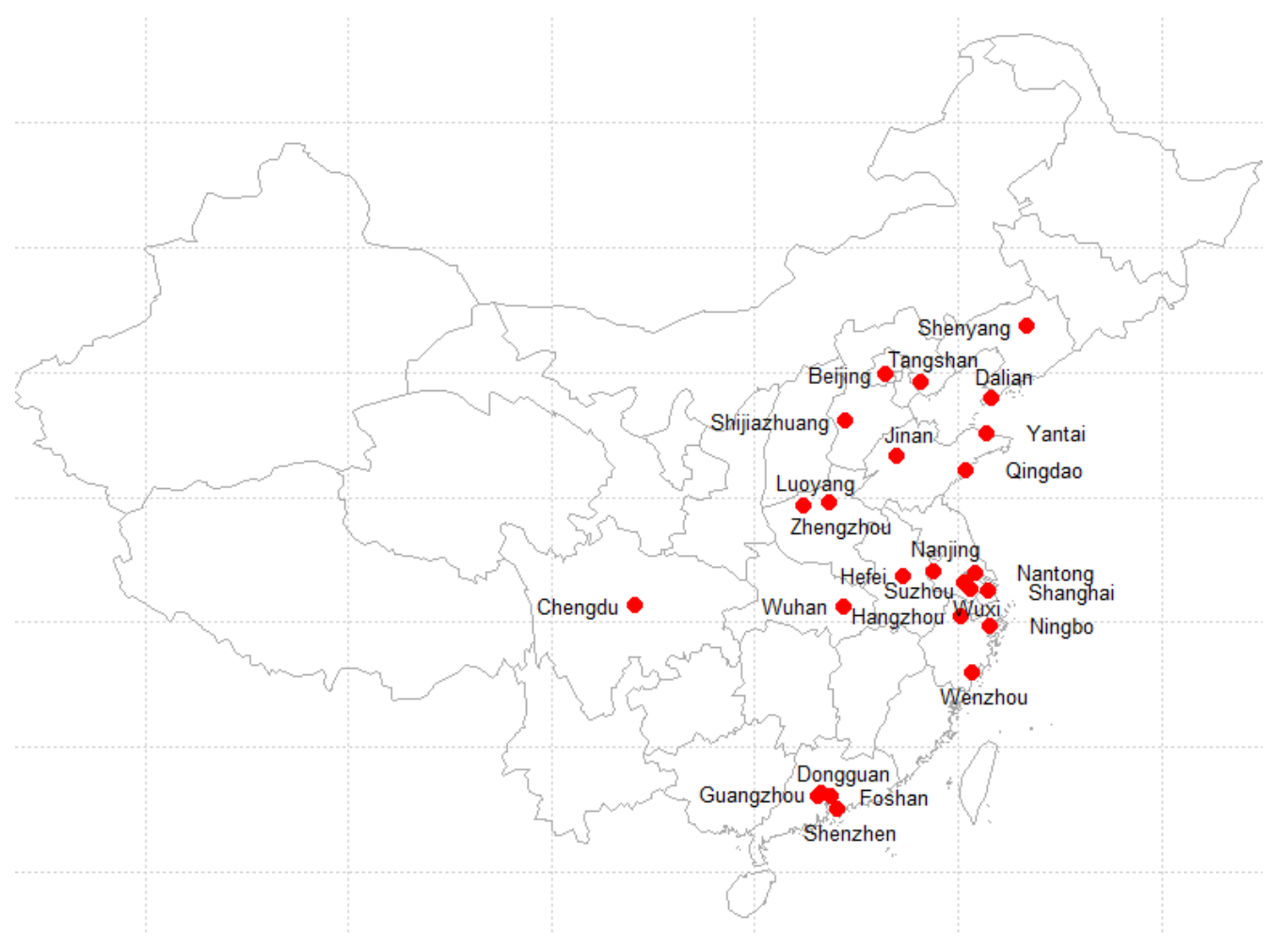


Figure 4. Average obstacleindex against the effective number of leaders

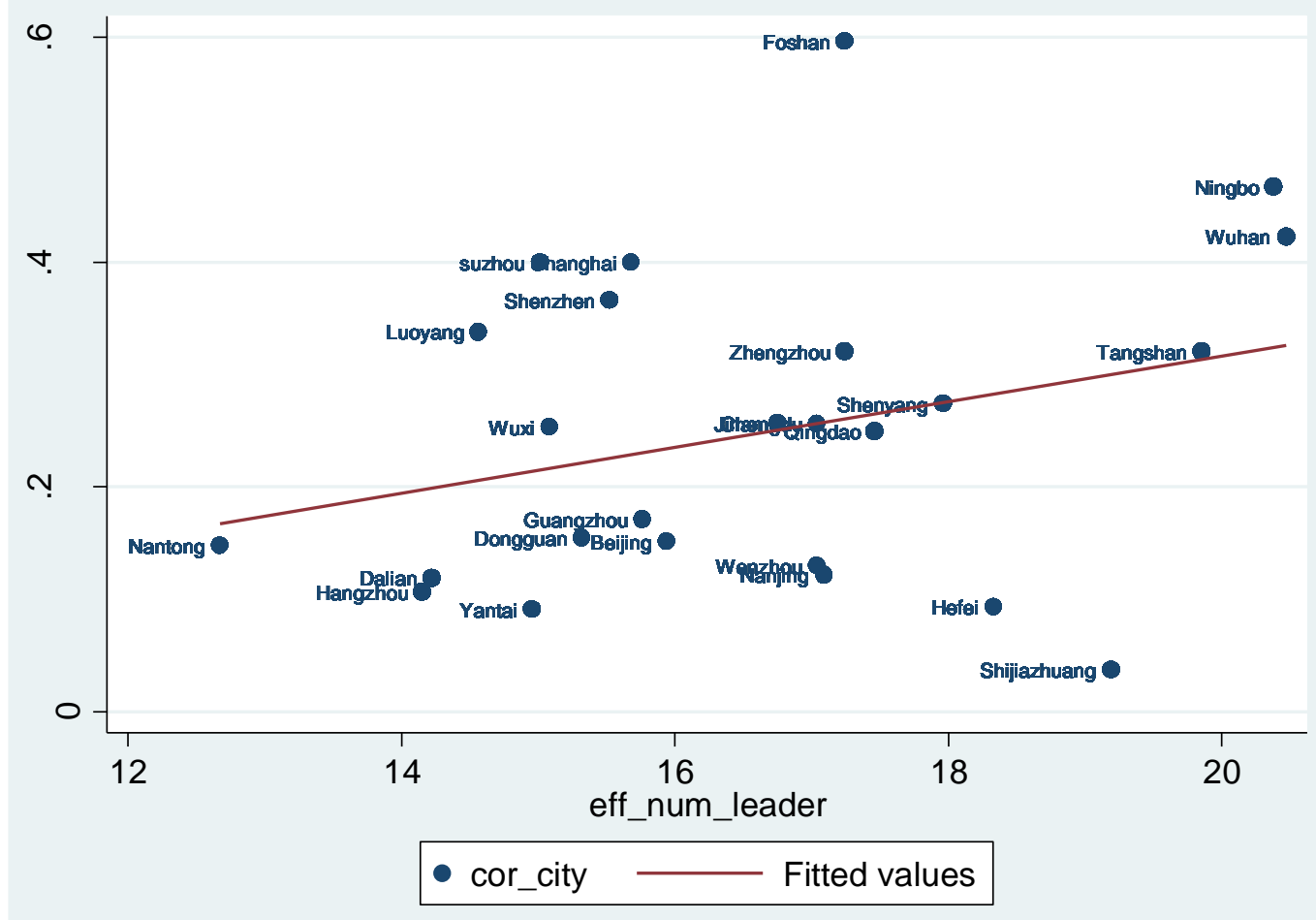


Figure 5. Marginal effects of leadership stability

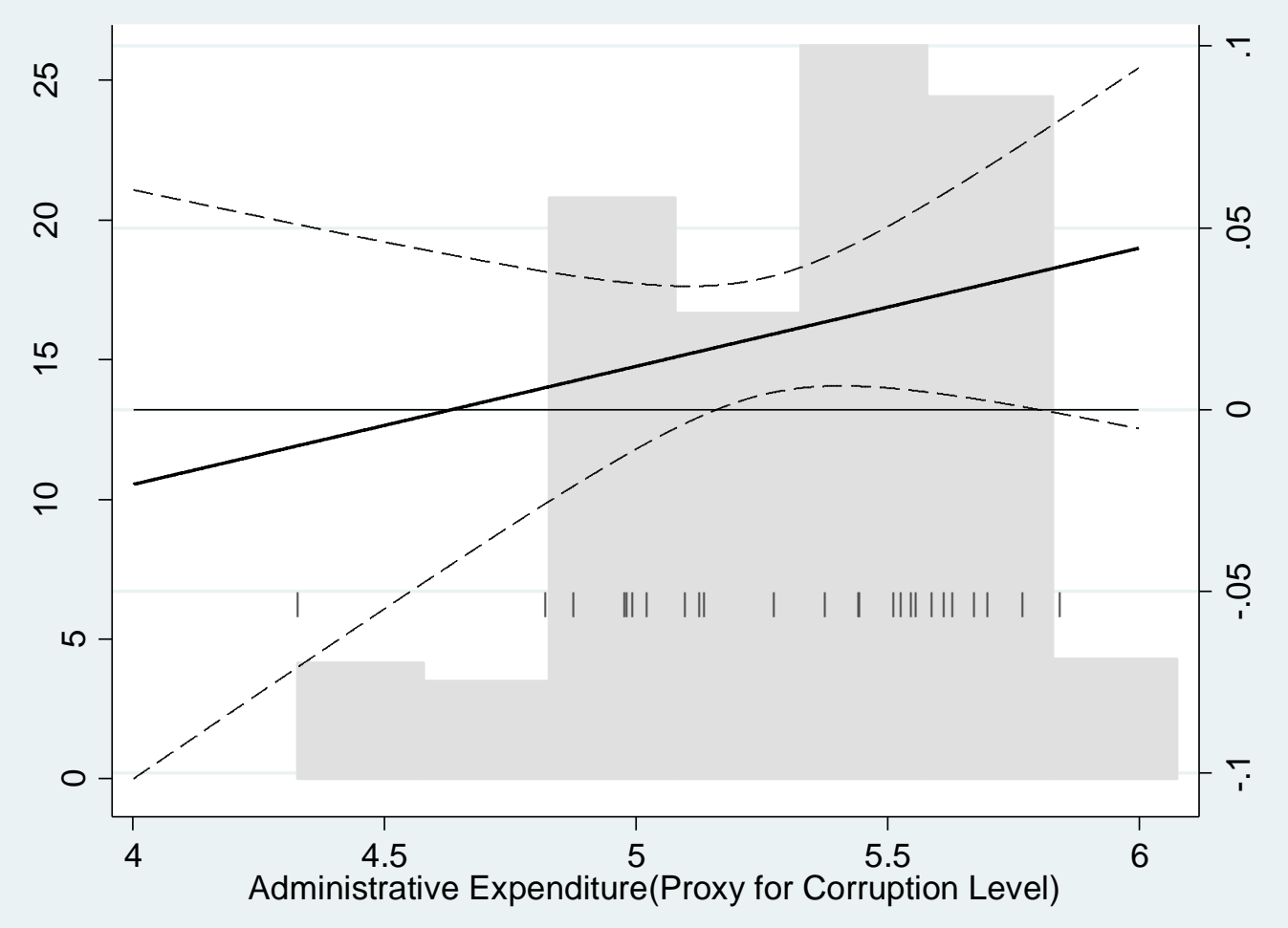

Notes: $y$-axis on the left denotes the percentage of observations corresponding to the histogram; y-axis on the right denotes the marginal effects of leadership stability; and $\mathrm{x}$-axis denotes the level of logged administrative expenditure per capita. When the two dotted lines (i.e., the upper and lower bounds of $95 \%$ confidence interval) both exceed 0 , the effect of leadership stability is significant. 
Table 1. Descriptive statistics

\begin{tabular}{lccccc}
\hline \hline Variables & Obs & Mean & Std. Dev & Min & Max \\
\hline Obstacleindex & 2700 & 0.244 & 0.43 & 0 & 1 \\
Eff_num_leader & 25 & 16.6 & 1.98 & 12.67 & 20.47 \\
Leader number & 25 & 23 & 2.39 & 19 & 28 \\
Max_top2_leader & 25 & 16.4 & 1.84 & 12 & 19 \\
Court_justice & 2700 & 2.64 & .2 .57 & 2.07 & 3.17 \\
Private Ownership & 2692 & 0.96 & 0.15 & 0.05 & 1 \\
Admin_exp (logged) & 25 & 5.31 & 0.37 & 4.33 & 5.84 \\
GDP per capita & 25 & 11.17 & 0.31 & 10.60 & 11.60 \\
Fisc_gdp & 25 & 0.11 & 0.03 & 0.06 & 0.20 \\
Industry_GDP & 25 & 0.45 & 0.09 & 0.19 & 0.60 \\
Urbanization & 25 & 0.46 & 0.17 & 0.10 & 0.78 \\
Population (logged) & 25 & 6.81 & 0.34 & 6.38 & 7.76 \\
\hline
\end{tabular}


Table 2. Effect of leadership stability on obstacleindex

\begin{tabular}{|c|c|c|c|c|}
\hline \multirow[b]{2}{*}{ VARIABLES } & \multicolumn{4}{|c|}{ Dependent Variable: Obstacleindex } \\
\hline & (1) & $(2)$ & (3) & (4) \\
\hline Effective number of leaders & $\begin{array}{l}0.107 * \\
(0.057)\end{array}$ & $\begin{array}{l}0.108 * * \\
(0.055)\end{array}$ & $\begin{array}{l}0.112 * * \\
(0.054)\end{array}$ & $\begin{array}{l}0.104 * * \\
(0.047)\end{array}$ \\
\hline Share of private capital & & & $\begin{array}{c}0.387 \\
(0.398)\end{array}$ & $\begin{array}{c}0.281 \\
(0.405)\end{array}$ \\
\hline Court justice & & & $\begin{array}{l}-0.303 \\
(0.390)\end{array}$ & $\begin{array}{l}-0.122 \\
(0.430)\end{array}$ \\
\hline Fiscal income as share of GDP & & & & $\begin{array}{l}-0.739 \\
(4.941)\end{array}$ \\
\hline GDP per capita & & & & $\begin{array}{l}-0.504 \\
(0.513)\end{array}$ \\
\hline Industry output as share of GDP & & & & $\begin{array}{c}7.419 * * * \\
(1.959)\end{array}$ \\
\hline Urbanization & & & & $\begin{array}{l}-0.341 \\
(0.492)\end{array}$ \\
\hline Population (logged) & & & & $\begin{array}{c}0.626 \\
(0.500)\end{array}$ \\
\hline $\begin{array}{l}\text { Administrative expenditure } \\
\text { (logged) }\end{array}$ & & & & $\begin{array}{c}1.486 * * * \\
(0.464)\end{array}$ \\
\hline Firm size & NO & YES & YES & YES \\
\hline Firm industry & NO & YES & YES & YES \\
\hline Observations & 2,700 & 2,690 & 2,682 & 2,682 \\
\hline Log-likelihood & -1489 & -1463 & -1454 & -1379 \\
\hline Pseudo R-squared & 0.01 & 0.02 & 0.03 & 0.08 \\
\hline
\end{tabular}

Notes: Robust standard errors clustered at the city level. ***Significant at the $1 \%$ level.

**Significant at the $5 \%$ level. *Significant at the $10 \%$ level. 
Table 3. Effect of alternative measures of leadership stability

\begin{tabular}{|c|c|c|c|c|}
\hline \multirow[b]{2}{*}{ VARIABLES } & \multicolumn{4}{|c|}{ Dependent Variable: Obstacleindex } \\
\hline & (1) & (2) & (3) & (4) \\
\hline Number of Leaders & $\begin{array}{l}0.122 * \\
(0.071)\end{array}$ & $\begin{array}{c}0.102 * * \\
(0.049)\end{array}$ & & \\
\hline Max Top 2 Leaders & & & $\begin{array}{c}-0.149 * * * \\
(0.056)\end{array}$ & $\begin{array}{c}-0.167 * * * \\
(0.046)\end{array}$ \\
\hline Share of private capital & & $\begin{array}{c}0.309 \\
(0.397)\end{array}$ & & $\begin{array}{c}0.188 \\
(0.381)\end{array}$ \\
\hline Court justice & & $\begin{array}{l}-0.066 \\
(0.445)\end{array}$ & & $\begin{array}{l}-0.373 \\
(0.321)\end{array}$ \\
\hline Fiscal income as share of GDP & & $\begin{array}{c}3.475 \\
(4.907)\end{array}$ & & $\begin{array}{l}-2.431 \\
(4.639)\end{array}$ \\
\hline GDP per capita & & $\begin{array}{l}-0.352 \\
(0.492)\end{array}$ & & $\begin{array}{l}-0.767 \\
(0.537)\end{array}$ \\
\hline Industry output as share of GDP & & $\begin{array}{l}7.317 * * * \\
(1.960)\end{array}$ & & $\begin{array}{c}7.372 * * * \\
(1.649)\end{array}$ \\
\hline Urbanization & & $\begin{array}{l}-0.067 \\
(0.513)\end{array}$ & & $\begin{array}{l}-0.546 \\
(0.488)\end{array}$ \\
\hline Population (logged) & & $\begin{array}{c}0.351 \\
(0.521)\end{array}$ & & $\begin{array}{l}0.838 * * \\
(0.420)\end{array}$ \\
\hline $\begin{array}{l}\text { Administrative expenditure } \\
\text { (logged) }\end{array}$ & & $\begin{array}{c}1.421 * * * \\
(0.501)\end{array}$ & & $\begin{array}{c}1.526 * * * \\
(0.394)\end{array}$ \\
\hline Firm size & YES & YES & YES & YES \\
\hline Firm industry & YES & YES & YES & YES \\
\hline Observations & 2,690 & 2,682 & 2,690 & 2,682 \\
\hline Log-likelihood & -1453 & -1379 & -1455 & -1369 \\
\hline Pseudo R-squared & 0.03 & 0.08 & 0.03 & 0.08 \\
\hline
\end{tabular}


Table 4. Effect in subsamples based on firm size and sector characteristics

\begin{tabular}{|c|c|c|c|c|c|}
\hline \multirow[b]{3}{*}{ VARIABLES } & \multicolumn{5}{|c|}{ Dependent Variable: Obstacleindex } \\
\hline & small firms & medium-sized & large firms & $\begin{array}{l}\text { highly } \\
\text { regulated }\end{array}$ & $\begin{array}{c}\text { less } \\
\text { regulated }\end{array}$ \\
\hline & $(1)$ & (2) & (3) & $(4)$ & $(5)$ \\
\hline Effective number of leaders & $\begin{array}{l}0.114^{*} \\
(0.058)\end{array}$ & $\begin{array}{c}0.176^{* *} \\
(0.070)\end{array}$ & $\begin{array}{c}0.056 \\
(0.057)\end{array}$ & $\begin{array}{r}0.145^{* *} \\
(0.072)\end{array}$ & $\begin{array}{c}0.090 * * \\
(0.040)\end{array}$ \\
\hline Share of private capital & $\begin{array}{l}-0.457 \\
(0.634)\end{array}$ & $\begin{array}{l}0.935 \\
(0.787)\end{array}$ & $\begin{array}{l}1.129 \\
(0.765)\end{array}$ & $\begin{array}{l}-0.087 \\
(0.546)\end{array}$ & $\begin{array}{c}0.407 \\
(0.532)\end{array}$ \\
\hline Court justice & $\begin{array}{l}-0.848^{*} \\
(0.455)\end{array}$ & $\begin{array}{l}0.316 \\
(0.615)\end{array}$ & $\begin{array}{c}0.184 \\
(0.529)\end{array}$ & $\begin{array}{c}0.202 \\
(0.676)\end{array}$ & $\begin{array}{l}-0.129 \\
(0.364)\end{array}$ \\
\hline Fiscal income as share of GDP & $\begin{array}{c}0.483 \\
(7.489)\end{array}$ & $\begin{array}{c}0.056 \\
(5.134)\end{array}$ & $\begin{array}{l}-1.751 \\
(5.901)\end{array}$ & $\begin{array}{l}-7.031 \\
(7.353)\end{array}$ & $\begin{array}{c}3.357 \\
(4.161)\end{array}$ \\
\hline GDP per capita & $\begin{array}{l}-0.132 \\
(0.656)\end{array}$ & $\begin{array}{l}-0.752 \\
(0.559)\end{array}$ & $\begin{array}{l}-0.627 \\
(0.645)\end{array}$ & $\begin{array}{c}-1.738 * * * \\
(0.607)\end{array}$ & $\begin{array}{c}0.035 \\
(0.518)\end{array}$ \\
\hline Industry output as share of GDP & $\begin{array}{c}10.335 * * * \\
(3.101)\end{array}$ & $\begin{array}{l}5.085^{* *} \\
(2.434)\end{array}$ & $\begin{array}{c}5.726 * * * \\
(1.787)\end{array}$ & $\begin{array}{l}5.439 * * \\
(2.581)\end{array}$ & $\begin{array}{c}7.928 * * * \\
(1.515)\end{array}$ \\
\hline Urbanization & $\begin{array}{l}-0.814 \\
(0.977)\end{array}$ & $\begin{array}{l}-0.683 \\
(0.604)\end{array}$ & $\begin{array}{c}0.300 \\
(0.512)\end{array}$ & $\begin{array}{l}0.128 \\
(0.704)\end{array}$ & $\begin{array}{l}-0.494 \\
(0.537)\end{array}$ \\
\hline Population (logged) & $\begin{array}{c}0.826 \\
(0.736)\end{array}$ & $\begin{array}{c}0.449 \\
(0.682)\end{array}$ & $\begin{array}{c}0.027 \\
(0.468)\end{array}$ & $\begin{array}{l}-0.433 \\
(0.756)\end{array}$ & $\begin{array}{l}0.889 * * \\
(0.434)\end{array}$ \\
\hline $\begin{array}{l}\text { Administrative expenditure } \\
\text { (logged) }\end{array}$ & $\begin{array}{l}1.308^{* *} \\
(0.616)\end{array}$ & $\begin{array}{l}1.975 * * * \\
(0.570)\end{array}$ & $\begin{array}{l}1.313^{* *} \\
(0.567)\end{array}$ & $\begin{array}{l}2.948^{* * *} \\
(0.648)\end{array}$ & $\begin{array}{l}0.856^{*} \\
(0.453)\end{array}$ \\
\hline Firm size & NO & NO & NO & YES & YES \\
\hline Firm industry & YES & YES & YES & NO & NO \\
\hline Observations & 970 & 935 & 748 & 874 & 1,818 \\
\hline Log-likelihood & -487.9 & -452.9 & -394.9 & -447.1 & -940.6 \\
\hline Pseudo R-squared & 0.12 & 0.09 & 0.08 & 0.08 & 0.07 \\
\hline
\end{tabular}

Notes: Robust standard errors clustered at the city level. ***Significant at $1 \%$ level. $* *$ Significant at $5 \%$

level. * Significant at $10 \%$ level. 


\section{Appendix A. Results for hierarchical linear models}

\begin{tabular}{|c|c|c|c|}
\hline \multirow[b]{2}{*}{ VARIABLES } & \multicolumn{3}{|c|}{ Dependent Variable: Obstacleindex } \\
\hline & (1) & $(2)$ & (3) \\
\hline Effective number of leaders & $\begin{array}{c}0.022 * * \\
(0.009)\end{array}$ & & \\
\hline Number of Leaders & & $\begin{array}{c}0.021 * * \\
(0.009)\end{array}$ & \\
\hline Max Top2 Leaders & & & $\begin{array}{c}-0.032 * * * \\
(0.009)\end{array}$ \\
\hline Share of private capital & $\begin{array}{c}0.045 \\
(0.053)\end{array}$ & $\begin{array}{c}0.046 \\
(0.053)\end{array}$ & $\begin{array}{c}0.040 \\
(0.053)\end{array}$ \\
\hline Court justice & $\begin{array}{l}-0.040 \\
(0.071)\end{array}$ & $\begin{array}{l}-0.020 \\
(0.072)\end{array}$ & $\begin{array}{l}-0.072 \\
(0.064)\end{array}$ \\
\hline Fiscal income as share of GDP & $\begin{array}{l}0.138 \\
(0.844)\end{array}$ & $\begin{array}{c}1.008 \\
(0.938)\end{array}$ & $\begin{array}{l}-0.173 \\
(0.759)\end{array}$ \\
\hline GDP per capita & $\begin{array}{l}-0.032 \\
(0.100)\end{array}$ & $\begin{array}{c}0.010 \\
(0.105)\end{array}$ & $\begin{array}{l}-0.085 \\
(0.089)\end{array}$ \\
\hline Industry output as share of GDP & $\begin{array}{c}1.236 * * * \\
(0.319)\end{array}$ & $\begin{array}{c}1.190 * * * \\
(0.326)\end{array}$ & $\begin{array}{c}1.240^{* * *} \\
(0.286)\end{array}$ \\
\hline Urbanization & $\begin{array}{l}-0.107 \\
(0.124)\end{array}$ & $\begin{array}{l}-0.051 \\
(0.123)\end{array}$ & $\begin{array}{l}-0.147 \\
(0.112)\end{array}$ \\
\hline Population (logged) & $\begin{array}{l}0.098 \\
(0.085)\end{array}$ & $\begin{array}{c}0.033 \\
(0.094)\end{array}$ & $\begin{array}{l}0.144 * \\
(0.076)\end{array}$ \\
\hline $\begin{array}{l}\text { Administrative expenditure } \\
\text { (logged) }\end{array}$ & $\begin{array}{c}0.203 * * \\
(0.090)\end{array}$ & $\begin{array}{l}0.173^{*} \\
(0.091)\end{array}$ & $\begin{array}{c}0.224 * * * \\
(0.080)\end{array}$ \\
\hline Firm industry & YES & YES & YES \\
\hline Firm size & YES & YES & YES \\
\hline Observations & 2,692 & 2,692 & 2,692 \\
\hline Number of cities & 25 & 25 & 25 \\
\hline Log-likelihood & -1402 & -1402 & -1399 \\
\hline
\end{tabular}




\section{Appendix B. Subsample of firms established before 2003, logit model}

\begin{tabular}{|c|c|c|c|}
\hline \multirow[b]{2}{*}{ VARIABLES } & \multicolumn{3}{|c|}{ Dependent Variable: Obstacleindex } \\
\hline & $(1)$ & (2) & (3) \\
\hline Effective number of leaders & $\begin{array}{c}0.115^{* *} \\
(0.051)\end{array}$ & & \\
\hline Number of leaders & & $\begin{array}{c}0.117 * * \\
(0.054)\end{array}$ & \\
\hline Max top two leaders & & & $\begin{array}{l}-0.176 * * * \\
(0.055)\end{array}$ \\
\hline Share of private capital & $\begin{array}{c}0.325 \\
(0.653)\end{array}$ & $\begin{array}{c}0.359 \\
(0.636)\end{array}$ & $\begin{array}{c}0.171 \\
(0.622)\end{array}$ \\
\hline Court justice & $\begin{array}{l}-0.156 \\
(0.363)\end{array}$ & $\begin{array}{l}-0.082 \\
(0.377)\end{array}$ & $\begin{array}{l}-0.466 \\
(0.293)\end{array}$ \\
\hline Fiscal income as share of GDP & $\begin{array}{c}1.424 \\
(4.855)\end{array}$ & $\begin{array}{c}6.437 \\
(4.688)\end{array}$ & $\begin{array}{l}-0.692 \\
(4.878)\end{array}$ \\
\hline GDP per capita & $\begin{array}{l}-0.568 \\
(0.593)\end{array}$ & $\begin{array}{l}-0.393 \\
(0.564)\end{array}$ & $\begin{array}{l}-0.849 \\
(0.622)\end{array}$ \\
\hline Industry output as share of GDP & $\begin{array}{c}8.208 * * * \\
(2.180)\end{array}$ & $\begin{array}{c}8.117 * * * \\
(2.193)\end{array}$ & $\begin{array}{c}8.210^{* * *} \\
(1.811)\end{array}$ \\
\hline Urbanization & $\begin{array}{l}-0.061 \\
(0.519)\end{array}$ & $\begin{array}{c}0.254 \\
(0.541)\end{array}$ & $\begin{array}{l}-0.300 \\
(0.551)\end{array}$ \\
\hline Population (logged) & $\begin{array}{l}1.080^{*} \\
(0.584)\end{array}$ & $\begin{array}{c}0.755 \\
(0.605)\end{array}$ & $\begin{array}{c}1.391 * * * \\
(0.510)\end{array}$ \\
\hline $\begin{array}{l}\text { Administrative expenditure } \\
\text { (logged) }\end{array}$ & $\begin{array}{c}1.701 * * * \\
(0.506)\end{array}$ & $\begin{array}{c}1.625^{* * *} \\
(0.546)\end{array}$ & $\begin{array}{c}1.740 * * * \\
(0.448)\end{array}$ \\
\hline Firm industry & YES & YES & YES \\
\hline Firm size & YES & YES & YES \\
\hline Observations & 1,491 & 1,491 & 1,491 \\
\hline Log-likelihood & -769.3 & -768.8 & -764.2 \\
\hline Pseudo R-squared & 0.09 & 0.09 & 0.09 \\
\hline
\end{tabular}

